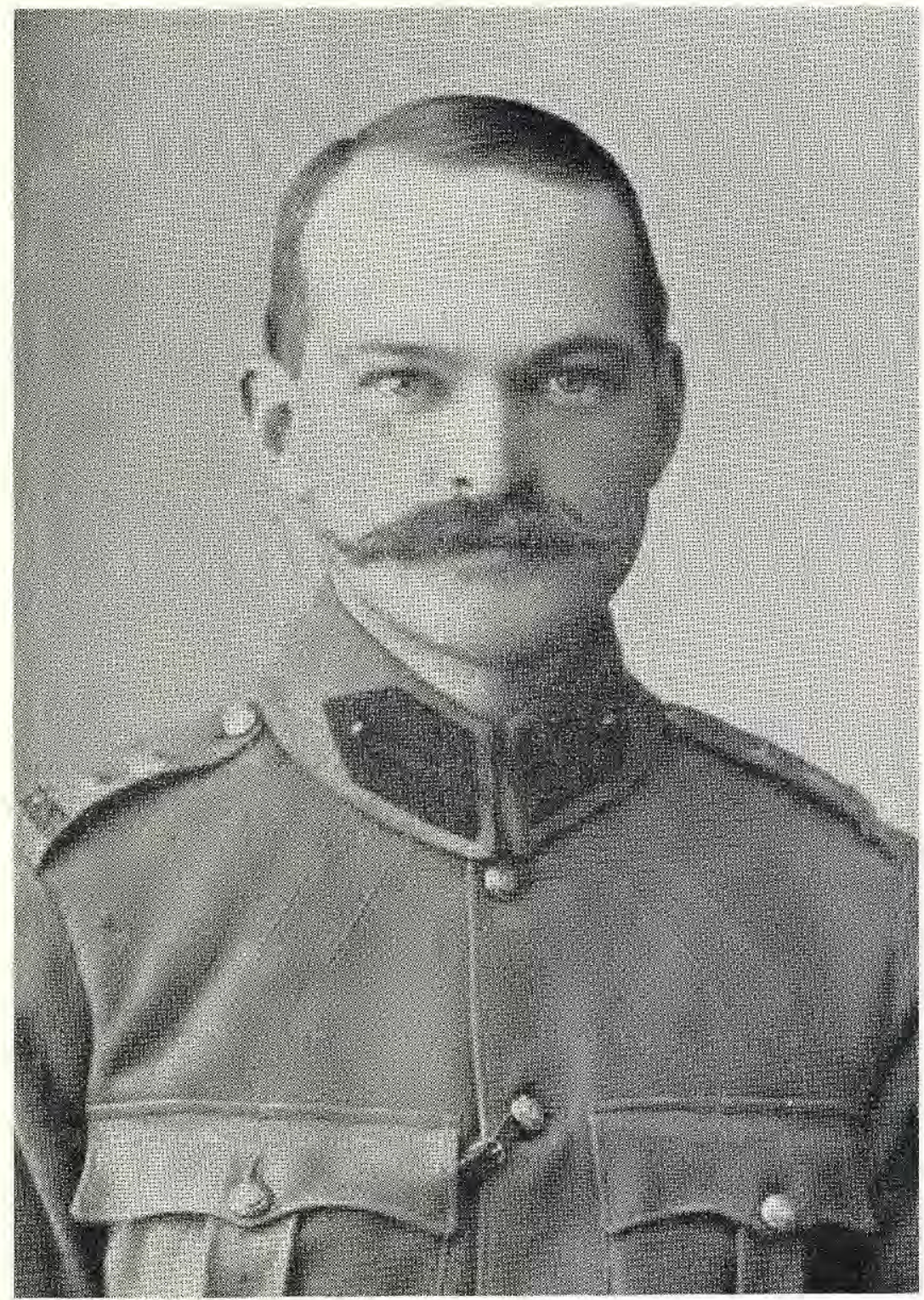




\section{MATTHEW LOUIS HUGHES AND UNDULANT FEVER}

Lieutenant-Colonel G. W. G. HUGHES, D.S.O., M.R.C.S., L.R.C.P., R.A.M.C.(Retd.) Dr. M. H. HUGHES, D.M., F.C.Path., Dip.Bact.

THE centenary of the birth of Matthew Louis Hughes passed without comment in 1967, but the occasion of the Clinical Meeting of the British Medical Association in Malta in 1969 makes the time an appropriate one to repair the omission. M. L. Hughes' classic monograph on undulant fever was the fruit of his experience as a young Army Medical Officer in Malta and it has won for him a permanent place in medical history.

M. L. Hughes was the second son of Emilius Hughes, C.B., C.M.G., of the Army Commissariat, later Colonel, Army Service Corps; his mother, Mary Sandys Emily Louis, was the daughter of an officer in the Royal Horse Artillery and a grand-daughter of one of Nelson's admirals, Sir Thomas Louis, Bart. Louis Hughes (he was always known by his second name) was born at Yokohama, where his father was then stationed, on 7th July, 1867. In the following year Emilius Hughes was posted to Canada where in May, 1869, tragedy struck the young family when Louis' mother, aged only 23, and his elder brother Gordon both died of diphtheria. Later in 1869 Emilius returned to England and enlisted the help of his father and stepmother in looking after Louis. Three years later, in 1872, Louis' father married again; his second wife always treated Louis as one of her own family but as he was older than the other children he was often left in England when the family went overseas. At the age of nine Louis was sent to King's College School (Lyle, 1935), where his father and uncles had been educated; at that time it was a gloomy place in the basement of Somerset House where the playground facilities were deplorable and the teaching mediocre.

In September, 1885, Louis followed his uncles and cousins to the Medical Department of King's College. He became an Assistant Demonstrator of Anatomy while a student and in 1889 qualified as M.R.C.S., L.R.C.P., and L.S.A. In 1890 he was successful in the competitive entrance examination for the Army Medical College at Netley (Obituary, 1899). Among the staff at Netley was Assistant Professor Major (later Sir) David Bruce who had published (Bruce, 1887) his discovery of a micrococcus in the spleens of soldiers who had died of Malta fever; it was no doubt this contact with Bruce at Netley which caused Hughes to develop his interest in Malta fever.

Hughes passed out of Netley at the head of the list in 1890 and was awarded the Parkes Memorial Prize. In December, 1890, he was posted to Malta. In 1891 Emilius Hughes was also posted to Malta as A.A.G. and was accompanied by his second wife and her children. Louis was able for a time to share their spacious quarters in the old Auberge de France. At this time he was an attractive young man with a fresh complexion and rather a heavy moustache. In Malta, Louis met Kate Winifred Simpson, a doctor's daughter who had come out to Malta on a visit to her sister, Mrs. Godfery, and they were married in St. Paul's Anglican Cathedral in Malta on 24th September, 1894.

Louis Hughes had not been long in Malta before he showed his interest in Malta fever by the first of a series of papers which he published in English, French and Italian medical journals. In the second of these papers (Hughes, 1893) he was the first to confer the specific epithet on the organism which is now known to bacteriologists as Brucella melitensis: Hughes' actual words were:- "In the year 1887 a micro-organism, which I shall call the "streptococcus Miletensis" was discovered in Malta by Surg. Capt. 
Bruce ...."The Mediterranean Naturalist in which this statement was published abounds with misprints and it may be accepted (Bacteriological Code, Rule 27.4 (International Committee, 1958)) that Hughes meant the name to be melitensis, the term which he later claimed in his monograph that he had bestowed upon Bruce's organism. Hughes' paper was published on 1st March, 1893 and it is puzzling to note that in a paper published on 1st April of that year Bruce himself referred (in the past tense) to "ce micrococcus que j'ai appelé Micrococcus melitensis" (Bruce, 1893). Whether or not Bruce had previously named his organism, it is a fact that Hughes achieved the prior publication of the specific epithet melitensis. The two men did not quarrel over this matter for they joined in two papers published in 1893 and Hughes, in his monograph, later proposed the amended, but invalid, name melitensis vel Brucii.

In 1893 Hughes' work in Malta was temporarily interrupted by his appointment as Special Commissioner to investigate an outbreak of typhus at Benghazi, in Cyrenaica. In 1896 both he and his wife contracted Malta fever and he was invalided home to England. His first task after his recovery was to finish the book upon which he had been working in Malta and Macmillan published his " Mediterranean, Malta or Undulant Fever" (Hughes, 1897) upon which his reputation rests.

Hughes' monograph has been praised by many later writers. Sir William Osler (1907) referred to "Hughes, on whose important work I have freely drawn". Huddleson (1943) called the book " an excellent description of brucellosis". Sir Weldon DalrympleChampneys (1960) spoke of the book as a "famous monograph . . . . which in the opinion of all who have made a serious study of this subject deserves to be numbered among the great classical descriptions of disease on account of its clarity, conciseness, completeness, acute observation and sound judgement. For all these reasons it did much to advance the study of undulant fever." Sir Graham Wilson and A. A. Miles (1964) referred to "Hughes, whose clinical study has never been improved upon". Few doctors can have written a book at the age of 30 which has continued to receive such praise from acknowledged experts on the subject for nearly 70 years after publication.

The name ' undulant fever' was coined by Hughes after careful consideration because he had come to disapprove of a limiting geographical term like 'Malta fever' for a disease of which the distribution had not been defined. Among the many detailed case reports in his book is included Hughes' description of his own illness and eventual recovery.

In one important respect Hughes went very badly astray, although he erred in good company, for in his discussion of the epidemiology of undulant fever he completely ruled out the likelihood of milk being a vehicle of infection. He had " met with no fact that would favour a causal connection between milk-supply and this fever". From his earliest days in Malta Hughes held the theory, unsupported by any positive evidence, that Micrococcus melitensis infection was acquired by the inhalation of dried faecal material containing the organism. The truth in this matter eluded all the other workers on the disease until Dr. (later Sir Themistocles) Zammit (1905) found agglutinins against Micrococcus melintensis in the sera of Maltese goats, and Major (later Sir William) Horrocks (1905) cultured the organism from goats' milk.

During his time in Malta Hughes succeeded in isolating the causative organism from the spleens of 14 soldiers who had died of undulant fever, thereby confirming the reports of Bruce (1887) and Gipps (1890). In his book he quoted the observation of 
Wright and Semple (1897) that the serum of patients with undulant fever contained specific agglutinins, but it is clear that Hughes did not have the opportunity to use the agglutination technique before his own illness compelled him to leave Malta. That he realised the diagnostic importance of the agglutination test is clear from a paper published shortly before his death in 1899 (Hughes, 1899). At the time when he did the work upon which his monograph was based the diagnosis of undulant fever in the living patient was still for Hughes entirely a clinical matter. The monograph was dedicated to Lord Lister who had been one of Hughes' chiefs at King's College Hospital. The author's own copy of the book, now in our possession, contains many manuscript additions and further references to the literature as if in preparation for a second edition. A necessary correction made by Hughes was the elimination of the Latin 'howler' "Index nominorum", perhaps a reflection on the quality of the classical teaching at King's College School.

After his recovery from undulant fever in 1897 Hughes took an active part in medical affairs. He took the D.P.H. and became an Associate of King's College, a Fellow of the Royal Medico-Chirurgical Society of London and of the Royal Institute of Public Health. In 1898 he was one of the secretaries of the Section of Tropical Diseases at the Edinburgh meeting of the British Medical Association at which he read a paper; it was here that Hughes met Sir Patrick Manson, the 'father of tropical medicine' who paid a glowing tribute to Hughes in an obituary notice in the British Medical Journal. From 1897 until 1899 Hughes served at Aldershot where, as Assistant Sanitary Officer, he was in charge of the bacteriological and chemical laboratories and found time to write the army "Manual of Chiropody".

In 1898 Sir Redvers Buller was appointed G.O.C. at Aldershot, where he had the opportunity to learn of Hughes' qualities as an officer and as a doctor. Louis Hughes' father had for many years been on friendly terms with Buller with whom he had served in Canada, in the Zulu War and at Tel-el-Kebir. It was natural, therefore, that when Buller left England in October, 1899, to take command in South Africa he should invite Louis Hughes to accompany him as his personal Staff Surgeon.

The history of the opening months of the Boer War must be read elsewhere. Suffice it to say that Sir George White was surrounded in Ladysmith with 12,000 of the best troops available in Natal and that Buller took personal charge of the attempt to relieve the besieged force. On 15 December, 1899, a frontal attack was launched upon the strong Boer position behind the Tugela river at Colenso. During the course of this action two batteries of Field Artillery advanced across an open plain to within a few hundred yards of the Boer position; the batteries came under a murderous fire and when they had fired off all their ammunition the surviving gunners were forced to abandon the guns and take cover in a donga a little to the rear. Buller went forward himself with his staff to superintend efforts to retrieve the guns from their exposed position, efforts which were the occasion of feats of gallantry which resulted in the award of no fewer than 8 V.Cs. including that of Major (later Sir William) Babtie, R.A.M.C. As Buller and his staff moved forward they came under heavy fire; Louis Hughes left the staff to assist Lieut. E. T. Inkson, R.A.M.C. attached to the gunners, in attending the casualties and was almost immediately fatally wounded. Inkson himself won the V.C. some weeks later in another engagement.

By the death of Captain M. L. Hughes at the age of 32 the R.A.M.C. lost a gallant 
officer and a medical scientist who would assuredly have made his mark. As well as his famous monograph he published 20 scientific papers during his short career. Hughes' widow died as recently as 1967 , a few days after the death of their only son, a Roman Catholic priest who was formerly prominent in academic circles in Malta and latterly was on the staff of Ampleforth College.

\section{Acknowledgements}

We are grateful for the invaluable assistance of the librarians at the Winchester Medical Centre (Mrs. E. M. Priest), the British Medical Association (Mr. F. M. Sutherland), the Royal Army Medical College, the Central Public Health Laboratory and the Natural History Museum.

\section{REFERENCES}

BRUCE, D. (1887). Practitioner, 39, 161.

BRUCE, D. (1893). Ann. Inst. Pasteur 7, 289.

DalRYMPLE-ChaMPNEYS, Sir W. (1960). "Brucella Infection and Undulant Fever in Man". Oxford University Press, London.

Grpps, A. G. P. (1890). Trans. epidem. Soc. Lond. 9, 76.

Horrocks, W. (1905). Report of the Commission on Mediterranean Fever. Part 3, p.84. Harrison, London. HudDleson, J. F. (1943). " Brucellosis in Man and Animals". 2nd Ed. Commonwealth Fund, New York.

HuGHES, M. L. (1893). Medit. Naturalist 2, 325.

Hughes, M. L. (1897). “Mediterranean, Malta or Undulant Fever ". Macmillan, London.

Hughes, M. L. (1899). J. trop. Med. 1, 210.

InTERnATIONAL COMmitTeE ON BACTERIological Nomenclature (1958). "International Code of Nomenclature of Bacteria and Viruses. Bacteriological Code". Iowa State College Press. Ames.

LYLE, H. W. (1935). "King's and some King's Men". Vol. 1. Oxford University Press, London.

ORITUARY. (1899). Brit. med. J. ii, 1757.

OsLer, W. (1907). "Principles and Practice of Medicine". 6th Ed. Appleton, London.

WrLson, Sir G. S. and Miles, A. A. (1964). "The Principles of Bacteriology and Immunity". 5th Ed. Arnold, London.

WRIGHT, A. E. and Semple, D. (1897). Brit. med. J. i, 1214.

ZaMmIT, T. (1905). Report of the Commission on Mediterranean Fever. Part 3, p. 83. Harrison, London.

(Also family papers in our possession, and personal recollections of G.W.G.H.)

\section{MATTHEW LOUIS HUGHES-BIBLIOGRAPHY}

1892 Investigations into the aetiology of Mediterranean fevers. Lancet ii, 1265.

1893 The natural history of certain fevers occurring in the Mediterranean. Medit. Naturalist 2, 299, 325 and 332.

1893 Sur une forme de fièvre fréquente sur les côtes de la Méditerranée. Ann. Inst. Pasteur 7, 628.

1893 Sur une forme de fièvre fréquente sur les côtes de la Méditerranée. Rif. med.

1893 (with Bruce, D. and Westcott, S.) Notes on Mediterranean or Malta fever. Brit. med. J. ii, 58.

1893 (with Bruce, D. and Fazio, E.) La febbre mediterranea e la febbricola nostrana. Revist. internat. d'Igiene 10, 394.

1893 (with Bruce, D. and Fazio, E.) La febbre mediterranea e le febbricola nostrana. Rif. med. i and iii. 
1894 The diagnosis between enteric fever and the remittent fever of the Mediterranean. Med. Mag.(Lond.) 3, 152.

1895 The fevers of India and the Mediterranean. Lancet i, 574.

1896 Note on the endemic fever of the Mediterranean. Proc. Roy. med.-chir. Soc. (Lond.) $8,174$.

1896 Note on the endemic fever of the Mediterranean. Med.-Chir. Trans. 79, 209.

1896 The endemic fever of the Mediterranean. Brit. med. J. i, 972.

1896 Undulant (Malta) fever. Lancet ii, 238 and 517.

1897 Mediterranean Malta or Undulant Fever. Macmillan, London.

1897 The endemic fever of the Mediterranean. Lancet i, 608.

1898 The unclassified fevers of the tropics. Brit. med. J. ii, 865.

1899 Undulant (Malta) fever. J. trop. Med. Hyg. 1, 210.

1899 (with Healey, C. W. R.) An acute epidemic of gastro-enteritis attributed to foodpoisoning. Lancet ii, 1223.

1899 Group of cases of malarial fever from West Africa including a case of black-water fever. J. trop. Med. Hyg. 1, 292.

1899 The geographical distribution of undulant (Malta) fever. Lancet ii, 610.

1899 The geographical distribution of undulant (Malta) fever. Brit. med. J. ii, 657.

Brit. med. J. (1899) 11, 1757.

\section{Obituaries}

Lancet (1899) ii, 1766. 